\section{Mr Benn's Parish}

Sir,--A statement in your article "Mr Benn's Parish" (Nature, 221, 297; 1969) is a little uncertain in its meaning but could be interpreted in a sense that is unfair to British industry and presents an inaccurate picture so far as Harwell is concerned.

The article included the following sentence: "The announcement that Harwell was ready to undertake industrial work, two years or so ago, is said to have produced only two replies from industry." If this is taken to mean that in two years Harwell has received only two enquiries from British industry, then it is very far from true.

To take one example, the Harwell Ceramics Centre (set up in January 1967) had received some 650 enquiries from industry by the end of December 1968 (many of which were stimulated by the regional offices of the Ministry of Technology). Again, during the same period, the Non-Destructive Testing Centre had over 170 technical problems put to it by industry and the NDT information service received nearly 650 queries. Industry's initial response to the booklet, "Harwell and Industrial Research" (published last October), was at the rate of 20-30 replies a day.

I think you will agree that this is a most encouraging response from industry and very different from that suggested in your article.

\section{Yours faithfully,}

\section{A. H. S. Matterson}

AERE,

Commercial Office, Building 329.2,

Harwell,

Didcot, Berkshire.

\section{More Children for Science}

SiR,-May I make one small correction to your succinct and useful report (Nature, 221, 607; 1969) on the Birmingham meeting about the shortage of science pupils ? The first of the points attributed to me in the discussion should be that science gets more blame for the bad features of the modern world than credit for the good ones and I suggested that teachers should help to redress the balance.

$$
\text { Yours faithfully, }
$$

Department of Physics,

JOHN WALKER

University of Birmingham.

\section{University News}

Professor R. C. Lewontin has been named chairman of the committee on evolutionary biology at the University of Chicago.

Dr J. S. Brimacombe, University of Birmingham, has been appointed to the Roscoe chair of chemistry at the University of Dundee.

Dr C. E. Lewis, University of Kansas, has been appointed professor of social medicine and assistant director of the Centre for Community Health and Medical Care at Harvard University.

Dr H. W. Woolhouse, University of Sheffield, has been appointed professor of botany at the University of Leeds.

Dr E. R. Gilliland has been appointed to the recently established Warren K. Lewis professorship of chemical engineering at the Massachusetts Institute of Technology.

Mr P. A. Bramley, Plymouth General Hospital and Royal Cornwall Hospital, has been appointed professor of dental surgery at the University of Sheffield.
The name of the sub-department of Radiological Physics at the University of Sheffield is to be changed to Medical Physics, and the title of Honorary Lecturer in Radiological Physics has been altered to Honorary Lecturer in Medical Physics.

\section{Appointments}

Dr W. Marshall, director of the Atomic Energy Research Establishment, Harwell, has been appointed director of the Research Group, which includes the Culham Laboratory as well as Harwell.

Dr W. C. Hamilton, Brookhaven National Laboratory, New York, has been elected president of the American Crystallographic Association. Dr D. P. Shoemaker, Massachusetts Institute of Technology, is the association's new vice-president.

Dr R. Serber, University of Columbia, has been named vice-president elect of the American Physical Society. Dr B. D. Loncarevic has been appointed to the new position of assistant director of the Atlantic Oceanographic Laboratory at Dartmouth, Nova Scotia.

\section{Announcements}

The Chemistry Society will be awarding the CordayMorgan Medal and Prize for the year 1968. There are three awards to be made for published work in different branches of chemistry. Further details can be obtained from the Scientific Affairs Officer, The Chemical Society, Burlington House, London WIV OBN. The Chemical Society will also award twenty research fund grants of $\mathfrak{\$ 5 0}$ each for 1970 . Preference will be given to those working in less-well-endowed establishments. Details can be obtained from the Administrative Officer.

An Environmental Mutagen Society has been formed. The purpose of the society is to encourage interest in and study of mutagens in the human environment. Membership application forms may be obtained from the Secretary, S. S. Epstein, Children's Cancer Research Foundation, Inc., 35 Binney Street, Boston, Massachusetts 02115 , USA.

The Council of the Institute of Physics and the Physical Society has approved the formation of a Computational Physics Group, which will be concerned with the whole subject of the use of computers in physics. Details may be obtained from the Registrar, The Institute of Physics and the Physical Society, 47 Belgrave Square, London SW1.

A limited number of awards will be made to scientists with active interests in pure and applied biophysics who are planning to attend the Third International Biophysics Congress, to be held in Cambridge, Massachusetts, August 29-September 3, to help cover their expenses. Application forms and details can be obtained from Third International Biophysics Congress, Room 20B-221, MIT, Cambridge, Massachusetts 02139, USA.

\section{International Meetings}

May 5, Organization and Management of Research and Development, London (Meetings Officer, The Institute of Physics and the Physical Society, 47 Belgrave Square, London SW1).

July 28-31, Computational Physics, Culham (Meetings Officer, The Institute of Physics and the Physical Society, 47 Belgrave Square, London SW1).

August 28-September 5, Nutrition, Prague (Secretariat, VIIIth International Congress of Nutrition, Office of the Secretary-General, Institute of Human Nutrition, Budejovicka 800, Prague 4, Czechoslovalkia). 
September 2-6, Molecular Structure and Spectroscopy, Ohio (Professor K. Narahari Rao, Molecular Spectroscopy Symposium, Department of Physics, Ohio State University, 174 West 18th Avenue, Columbus, Ohio 43210, USA).

September $15-17$, Calorimetry in Chemical and Biological Sciences, Guildford (Dr R. J. Irving, Departmont of Chemistry, University of Surrey, Battersea Park Road, London SW11).

September 16-19, Solid State Devices, Exeter (Meetings Officer, The Institute of Physics and the Physical Society, 47 Belgrave Square, London SW1).

September 21-26, Papermaking Systems and their Control, Oxford (Technical Section, British Paper and Board Makers' Association Incorporated, Plough Place, Fetter Lane, London EC4).

Septembor 22-24, Use of Cyclotrons in Chemistry, Metallurgy and Biology, Oxford (Dr C. B. Amphlett, Chemistry Division. AERE, Harwell, Didcot, Berkshire, UK).

September 29-October 1, Bioelectrical Impedance, New York (Jean Fitzpatrick, New York Academy of Sciences, 2 East 63 Street, New York, NY 10021).

\section{Sabbatical Itinerants}

In the hope of providing some practical assistance in the good cause of mobility between laboratories, Noture is proposing to advertise the needs for housing of families about to take up periods of sabbatical leave. To begin with, no charge will be made for advertisements like this. It is hoped that a period of experiment will show what form these advertisements could most usefully take and whether they are effective.

Wanted : Furnished flat or house in London for young Dutch psychopharmacologist, his wife and small baby, from April 22 for three months ; preferably within easy reach of the London Hospital, F1. Please contact Miss J. Bacon, Department of Pharmacology and Therapeutics, the London Hospital Medical College, Turner Street, London E1 (Tel. No. (01) 2470644 ext. 10).

Vacant: Fully furnished new house in plcasant Essex village of Ingatestone (Brentwood 5 miles; London 25 miles). Three bedrooms, large lounge, kitchen and usual conveniences; full central hcating (gas); telephone ; garage; gardon. $10 \mathrm{~min}$ from station with casy access to London $(40 \mathrm{~min})$. Available from August 1, 1969, for 12-14 months. Please contact Dr J. B. Clark, Biochemistry Department, St Bartholomew's Hospital Medical College, University of London, Charterhouse Square, London EC1.

Wanted : Furnished flat or house (2 or 3 bedrooms) in Naples for American professor, wife, daughter (16) and son (4), Fchruary to September 1970, conveniently situated for access to LIGBA. Please contact Dr (4. Wolf, 56-235, Massachusetts Institute of Technology, Cambridge, Massachusetts 02139, USA.

Vacant: Furnished contemporary 5-bedroom, 2bathroom house in Lexington, Massachusetts; large garden, share in community swimming pool 5 minutes walk from house. Outstanding schools, bus-line to Harvard square nearby (access to Harvard, MIT) (25 min ride). Stationwagon (middle-aged) thrown in. February 1 to September 1970. Please contact Dr G. Wolf, 56-235, MIT, Cambridge, Massachusetts 02139, USA.

\section{BRITISH DIARY}

Monday, March 24

institution of Electrical ENaineers (at Savoy Place, London, WC2), at 2 p.m. - Colloquium on "Null Detectors".

Institution of Electrical Engineers (at Savoy Place, London, WC2), at 5.30 p.m.-Mr J. L. Freris and Mr A. M. Sasson: "An Investigation of Load-Flow Problems".

Plastics Institute, London Seotion Engineering Subgroup at the "Coachmakers Arms", 88 Marylebone Lane, London, W1), at 6.15 p.m.Annual General Meeting, followed by Mr M. Tubbock: "The Cost of Moulds".

INSTITUTION OF THE RUBBER INDUSTRY, MANOHESTER SRCTTON (at the Renold Building, University of Manchester Institute of Science and Technology, Sackville street, Manchester 1), at 6.45, p.m.--Mr P. Albericci "IIistory of Non-Metallics in Aircraft Construcition"

Monday, March 24-Tuesday, March 25

BIOLOGICAL COUNCII CO-ORDINATING COMMTT'TEF FOR SYMPOSIA ON DRUG Actios (in the Mechanical Engineering Department, Imperial College, London, SW7) - Symposium on "Calcium and Cellular Function".

Monday, March 24-Wednesday, March 26

DIELEOTRICS DIscussion Grocr (at the Physical Chemistry Laboratory, Oxford)-Mecting on "Diclectric Aspects of High Field Phenomena (excluding breakdown) and Impurity Effects".

\section{Tuesday, March 25}

Soctety of Chemical Indestry, Plastics and Polymer Grodp (at Imperial College, London, SW7), at 10 a.m.-Symposium on "Ethylene/ Vinyl Acetate Copolymers",

South Mrdiands Metallurgical Association (at the Hotel Leofric, Coventry), at 7.15 p.m.-Mr H. M. Morgan: "It's Patented-so what?"

Tuesday, March 25-Wednesday, March 26

BRITISH SOCIETY FOR CELT BIOLOGY and the SOCIETY FOR GENERAI Mrorobiology (at the Middlesex Hospital Medical School, Cleveland Street, London, W1), at $9.30 \mathrm{a.m}$. daily-Meeting on "Fluorescence Microscopy in Biology",

Institution of Public Health Enginferss; Institution of Water ENGINEERS; and the INSTITUTE OF WATER POLLUTION CONTROL (in the

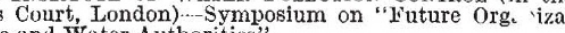

Tuesday, March 25-Thursday, March 27

Institete of Physics and the Physical Soclety (at the University of Nottingham) -..Meeting on "The Theory of Interactions Among Elcmentary Excitations in Solids and Liquids".

Royal Institution of Naval ARcmitects (at 10 Úpper Belgrave Street, Jondon, SW1), at 10 a.m. daily-Spring Meetings.

Tuesday, March 25-Friday, March 28

INSTITUTION of ELEOTRIOAL ENGINEERS (at Southampton)-Associatcd Conference on "Iasers and Optoelectronics".

Universaty of Bristor, Department of Agrjcultuke and HoRticulTURE (at Long Ashton Research Station)-Symposium on "Physiology of
Tree Crops".

\section{Wednesday, March 26}

SOCIETy OF Chamical INDUSTRy, FoOD Group (joint meeting with the DANISH SOCIETY OF FOOD TECHNOLOGY AND HYGIENE, in the Department of Chemistry, University of Reading), at 2.30 p.m.-Meeting on "Toxicological Problems of Animal Feeding".

UnIVERSTTY OF I.ONDON (at the Institute of Urology, 10 Henrietta Street, London, WC2), at 5 p.m.-Mr.J. D. Williams: "Disorders of the Prostate".

SOCTETY OF FNVIRONMENTAL FNGINFERS, PACKAGING GROUP (in the Department of Mechanical Engineering, Imperial College, London, SW 7), at for Naval Application.

Institution of Eleotronio and Radio EngrneEls, East Midland Ecrnion (at Newark Technical College), at 6.30 p.m.- Mr H. V. Sims: "Colour Television".

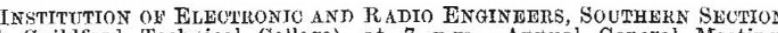
at Guildford Technical (College), at 7 p.m.-Annual Gencral Meeting followed by "Design Using Integrated Circuits" (speaker to be announced).

Wednesday, March 26-Thursday, March 27

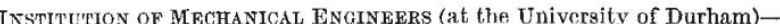
Symosium on "Maintenance Develonments in Process Industries".

Wednesday, March 26-Friday, March 28

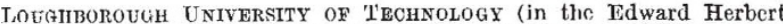
Building)-Symposium on "The Compatibility of Transport Systems",

Wednesday, March 26-Saturday, March 29

Instistition OF Mechanical ENGineERs, EDUCATION AND Training Group (at the University College of Walcs, Aberystwyth)-Second Conference on "Trends in the Education and Training of Professional Mechanical Enginecrs".

Thursday, March 27

SOCIETY YOR ELECTROCHEMISTRY, SOLID STATE SUB-GROUP (at Imperial

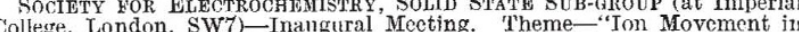
Collegre,
Solids".

SOCIETY ror Water TrEatment and Fxamination (in the Physics Department, Imperial College, London, SW7), at 9.30 a.m.-Scientific Papers. 